\title{
The Theme of Partition in Bapsi Sidhwa's Ice Candy Man
}

\section{OPEN ACCESS}

Volume: 8

Issue: 1

Month: December

Year: 2019

P-ISSN: 2320-2645

E-ISSN: 2582-3531

Received: 29.09.2019

Accepted: 01.11.2019

Published: 01.12.2019

Citation:

Ponmalar, SK. "The

Theme of Partition in

Bapsi Sidhwa's Ice

Candy Man." Shanlax

International Journal

of English, vol. 8, no. 1, 2019, pp. 71-73.

DOI:

https://doi.org/10.34293/

english.v8i1.1141

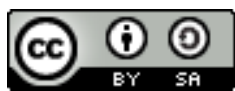

This work is licensed under a Creative Commons AttributionShareAlike 4.0 International License

\section{SK.Ponmalar}

Assistant Professor, Department of English,

Raja Doraisingam Goverment Arts College, Sivagangai, Tamilnadu, India

\section{Abstract}

Bapsi Sidhwa in her novel, Ice CandyMan focuses on the theme of partition of India along with several other themes like the tragic tales of uprooting wonderful dreams of Ranna and Ayah, enormous vacuity of lifeless air that fills the streets of Lahore and the betrayal of human trust. They are all linked with partition phenomenon which left a permanent scar on the memory of India's history. Though everyone seems to be affected by both political and religious horros, very few writers have written about it. Bapsi Sidhwa is one among them. With her artistic vision, she sweeps into a historically significant event of the division of nation.

Keywords: Migration, Communal Violence, Political Events, Diachronic World, Religious Prejudices, Treacherous, Fragmentation of the community, Psychological reactions.

British ruler's withdrawal after world war II paved the way for the partition of India into two countries, followed by the migration of people and the communal violence. Riots broke out everywhere in India, leading to personal tragedies in the lives of common people. Hindus, Muslims, and Sikhs who lived together in peace and harmony, found themselves strangers to one another and so they were inflicting brutalities. The pain of death and devastation left a lasting mark not only on the internal and external politics of both countries India and Pakistan, but still, the scars can be found in the lives of the individuals.

As 'Literature is the mirror of a Society,' the incidents occurred and changed the lives of the people on an unprecedented scale, were reflected in Literature. Due to the Politico-historical incident, the partition of India, every religion and community, met with many horrible incidents. Though fiction written about partition is meager compared with the production on the world wars and the French and Russian Revolutions, there are some writers who chose the theme of partition for their inscription in Literature.

Creative minds like Kushwant Singh, Chaman Nahal, AttiaHossain, MonoharMalgankar, Salman Rushdie, and BapsiSidhwa effectively depict the massacres of migration and the difficulties faced by the refugees. While woman writers like Arundhati Roy, Anita Desai, Shashi Deshpande, Bharati Mukherjee, Jhumpa Lahiri, ChitraBannerjee, Gauri Deshpande, etc. have focused on the realistic portrayal of female experiences and conflicts in various ways, BapsiSidhwa took up the topic devastation wreaked by India's partition, throwing light on individual and social pain in her novel, "Ice Candy Man". 
"Ice Candy Man," the most popular novel of BabsiSidhwa, appeared under the title, "Cracking India" in America has found a popular place among the partition literary works. Like "Ice Candy Man," Khushwant Singh's "Train to Pakistan" also depicts the theme of partition in terms of political events and also focuses the human dimension, which brings the sense of reality horror and believability. Against the backdrop of this scene, a committed love relation between a notorious character named Jugget Singh with a Muslim girl, Nooran. Salman Rushdie's "Midnight Children," like the above-mentioned novels, deals with the transition of India from British Colonialism to freedom and Self-governance. More Specifically, it focuses on the country's partition apart from display of technical novelties, use of magic realism, and stylistic Virtuosity.

BapsiSidhwa uses a child narrator persona as a narrative voice to lend a degree of innocent perception of the wretched partition mess. When the events are presented by a Polio-affected girl child narrator Lenny, one can feel the innocent Compassion and dramatic shocks at the intolerable violence that marks the latter part of the tale. Lenny is dependent on Ayah called Shanta, the beautiful, alluring girl from a Hindu family. The deepest bond between these two, sharing of secrets, pain, and pleasure, moves everyone. The big tragedy of "Ice Candy Man" is the painful snapping of that link between Lenny and Ayah. In the words of V.L.V.N Narendra Kumar,

"In Ice Candy Man, Sidhwa presents a diachronic world where the life of Lenny and her growth at all levels is in parallel time order. In other words, there is the history of Lenny, and there exists the chronology of the subcontinental partition tale. As historical time is linear and colonial, which is nothing but a record of depravity, cultural economic, political, and emotional east post-colonial novelist creates his own 'space' authenticity and belongingness by his 'English".

Sidhwa wants to draw the reader's attention to the tragic tales of the uprooting of wonderful dreams of Ranna, Ayah, and Lenny. From the beginning of the novel, there are discussions among the Parsis, Hindus, Muslims, and Sikhs. Though politics dominates even ordinary conversations, initially, they are free from religious prejudices. But when the tension increases, we can hear many voices raised both in favor of their religion. In the meeting of the Parsis convened in Lahore, the Parsis supported the formation of Pakistan, and this feeling is inspired by the communal political atmosphere.

At dinner parties also, the talks invariably turn at the current topic of partition based on religion. A Hindu, a Sikh, a British Inspector General of Police, and his wife, Mrs. Rogers, the green-eyed American wife of Sardar Ji, gather for a fine party, but they cannot remain free from a communal angle and political debate. When Lenny visits Imam Din's Village, PirPindo, there is togetherness among villagers of three different communities. But the Sikhs organize an attack on that village, enraged by what the Muslims did to their brothers in Lahore, Amritsar and other places. The outer show of brotherhood hides the feeling of fear and distrust. The people of freedom-loving, easy-going, and inquisitive find themselves amid confusion and complete ruin. They find partition is inevitable. The common men and women can do nothing to change it. Tolerance mutual love and harmonious coexistence have easily been shattered.

"Taking turn one by one; The Mali Hari, IceCandy-man, thee masseur, Sharbat Khan, Imam Din, and Sher Singh, all converge on this focal point. The Ayah is undiscriminativetowards all, and it is in this that she becomes a symbol of the composite culture that India is... A similar symbol of the unity of Indian religion provided by the visitors to the Queen's Park where men of all religions and creeds rub shoulders with one another. With the imminence of Partition, the Park presents a picture of different groups of diverse faiths keeping away from one another's company. A passion run high even when men of different communities talk and chat with one another" (Jagdev Singh 152)

Partition brings the division of the land, fragmentation of the community, self-destroying division of loyalties, love, and sympathy. Sidhwa picturises the effect of the religious passion aroused by the events leading to partition. The latter part of the novel describes the violence that engulfs the life of everybody. Sidhwa beautifully canvasses the 
realistic details of the personal level of life effected by partition events as well as the social level of Community life.

To evade talking of partition becomes difficult. When the people contemplate its inexorable march, they feel that it can't be avoided and so a melancholy shadow descends on them. In this process, their mental worlds stir up the feeling that other communities are no longer to be viewed as friendly, and so their mind is filled with sadness and frustration. The objects of love and amity are taken as a token of discord, which must be removed. The Scenario of all community people finding comfort in good and bad times under the roof of the Parsi family at the beginning of the novel is being changed now. There is Hari, Mali, Imam Bin, YousufBhai, Muchlro, Shankar, and many other visitors who get shelter there. Everyone wants to take care of the beautiful eighteen-year-old Hindu Ayah. To safeguard her in bad times, she is hidden away by the family until Ice-Candy-Man uses his tricks to nudge out the necessary information. This failure saddens everybody. Godmother's harsh treatment of Ice-Candy-Man makes him realize his utter weakness. He realizes, after the tides of partition days, violence has subsided, he is nothing but a worthless refuge of social madness.

Ice-Candy-Man is visibly shaken. Hishazed eyes dark frantically-like the sparrows he once trapped for the mems-as he glances atMini Aunty, the road, me, for sympathy for means of succor. And then his yellow eyes narrowed, he stares at God's mother with naked malevolence.

I See him now as Godmother sees him. Treacherous, dangerous, contemptible.
A destructive force that must be annihilated. 'You have permitted your wife to be disgraced!'

Destroyed her modesty! Lived off her womanhood!' says Godmother as if driven to recount the charges before an invisible judge. (248-49)

The most valuable point here is in this massive game of the unholy mix of religion and partition, the Parsi family emerges with the noble values of humanism, while the blood thirsty mobs roam around the streets, beating the drums of their respective religion raising the slogans of "Allah-oAkbar!" "Sat Siri Akal!Bole so Nihal." This novel is the master piece of BapsiSidhw, which shows her remarkable mastery over the technique of revealing the inner psychological reaction of the child in a highly symbolic manner. After witnessing the brutal killings of the roads, Lenny rushes to her room, and taking out her favorite doll asks a cousin to pull off its legs, and then she tears out its belly. This is the most moving depiction of the emotional turmoil she undergoes. At all levels this novel is full of dramatic tension, unexpected turns of events and behavior, tragic destinies of the individuals such as Ice-Candy-Man's betrayal, Lenny's naïve behavior, Godmother's epic lashing out, Ranna's agonies, and Imam's Din's rock-like stand against the attackers result from the historic event of partition.

\section{References}

Gaur, Rashmi. Bapsi Sidhwa's Ice-Candy Man, A Reader's Companion, Asia Book Club, New Delhi, 2004.

\section{Author Details}

Dr.SK.Ponmalar, Assistant Professor, Department of English, Raja Doraisingam Goverment Arts College, Sivagangai, Tamil Nadu, India, Email ID: c.ka.malar@gmail.com. 